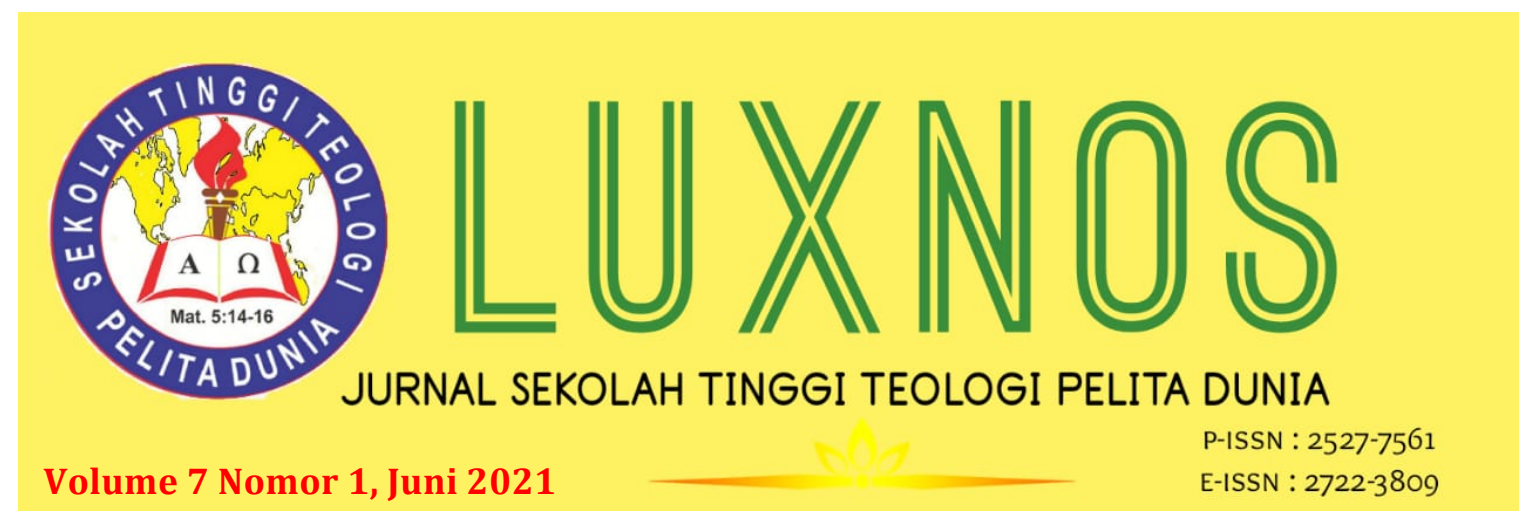

\title{
Kedaulatan Allah dan Pandemi Covid-19: Sebuah Tinjauan Biblis-Teologis
}

\author{
James A. Lola ${ }^{1}$ \\ Institut Agama Kristen Negeri Toraja \\ jnlola86@gmail.com \\ Donna Mutiara Junita Nainggolan ${ }^{2}$ \\ Sekolah Tinggi Teologi Pelita Dunia \\ donnamutiara71@gmail.com
}

\begin{abstract}
This literature research traces the biblical-theological study of God's sovereignty related to the Pandemic. The problem of pandemic itself, in tracing the Bible, is more associated with infectious diseases especially pestilence, in which infectious diseases are given by God as a punishment for human sin, as a warning of a greater danger and also as God's way to save His chosen people.
\end{abstract}

Keywords: God's Sovereignity, Infectious Diseases, Pandemic, Pestilence

Abstrak: Penelitian kepustakaan ini menelusuri kajian biblis-teologis tentang kedaulatan Allah berkaitan dengan pandemi (penyakit menular). Persoalan pandemi sendiri dalam penelusuran terhadap Alkitab lebih banyak dikaitkan dengan penyakit menular terutama penyakit sampar, di mana penyakit menular diberikan oleh Allah sebagai hukuman atas dosa manusia, sebagai peringatan akan bahaya yang lebih besar dan sebagai cara Allah untuk menyelamatkan umat pilihan-Nya. Artikel ini mencoba untuk menjelaskan hubungan antara kedua hal tersebut yaitu kedaulatan Allah dan persoalan pandemi yang muncul melalui pendekatan biblis-teologis. Hasil dari penelusuran menjelaskan bahwa tidak ada satu hal pun termasuk pandemi yang terjadi di luar kedaulatan Allah dan Allah dapat menggunakan pandemi ini sebagai cara Allah untuk melindungi alam ciptaan-Nya.

Kata Kunci: Kedaulatan Allah, Pandemi, Penyakit menular, Penyakit sampar 


\section{JURNAL LUXNOS}

Volume 7 Nomor 1, Juni 2021

\section{Pendahuluan}

Akhir tahun 2019 dan awal tahun 2020 merupakan tahun yang akan senantiasa dikenang dalam sejarah kehidupan manusia, karena pada saat itulah seluruh dunia dilanda oleh badai virus corona atau yang lebih dikenal dengan istilah Covid-19. Virus yang pertama kali ditemukan di Wuhan China ini dengan cepat menyebar ke seluruh dunia dan mengakibatkan hampir jutaan orang di dunia meninggal karena terinfeksi virus ini. Menurut data yang dilansir oleh situs resmi WHO pada tanggal 3 Maret 2021, sudah ada 114.140.104 orang yang terinfeksi virus Covid-19 di seluruh dunia dan angka kematian sudah mencapai 2.535 .520 orang. Benua Amerika menjadi benua dengan populasi terbesar yang terinfeksi virus ini, yakni 28.294 .809 orang dan diikuti oleh India dengan jumlah orang yang terinfeksi adalah 11.124.527 orang. Untuk Indonesia sendiri, jumlah orang yang terinfeksi sampai tanggal 3 Maret 2021, sudah mencapai 1.341.314 orang dengan angka kematian akibat virus ini adalah 36.325 orang. ${ }^{1}$ Dengan adanya tingkat penyebaran Covid-19 yang begitu cepat dan dampak kematian yang cukup besar, maka WHO sebagai badan kesehatan dunia melalui Direktur Jenderal WHO, Tedros Adhanom Ghebreyesus, kemudian menetapkan situasi ini sebagai bencana bagi dunia dan menyebutnya sebagai pandemi² sejak tanggal 11 Maret 2020. ${ }^{3}$

Pengaruh dari Covid-19 ini cukup signifikan, karena sejak ditetapkan sebagai pandemi, banyak kegiatan akhirnya dihentikan dan ditangguhkan untuk menekan angka penyebarannya. Kegiatan-kegiatan yang mengumpulkan banyak orang mulai dari kegiatan olahraga, kegiatan konser musik, pekerjaan di kantor, mall, bahkan ibadah di Gereja harus dihentikan untuk sementara waktu karena Covid-19 termasuk salah satu virus yang begitu cepat menyebar dan menular ke orang lain melalui kontak fisik. ${ }^{4}$ Penyebaran Covid-19 yang sangat cepat, membuat penulis tertarik untuk meneliti mengenai konsep penyakit menular yang menyebabkan pandemi dan kematian di seluruh dunia. Hal ini akan dikaji secara Biblis dan Teologis. Apa yang Alkitab katakan tentang penyakit menular (pandemi) dan bagaimana hubungan penyakit menular

1WHO Coronairus (Covid-19) Dashboard, https://covid19.who.int/table, diakes: 3 Maret 2021.

${ }^{2}$ Kata "Pandemi" dalam Kamus Besar Bahasa Indonesia (KBBI), berarti penyakit yang tersebar secara luas pada suatu wilayah, benua atau di seluruh dunia. Sedangkan menurut WHO, pandemi dimengerti sebagai sebuah wabah patogen yang menyebar dengan sangat cepat ke banyak wilayah dari orang ke orang sampai ke seluruh dunia.

${ }^{3}$ https://www.medcom.id/rona/kesehatan/dN60dMqk-ketahui-beda-wabah-pandemik-endemikdan-epidemik, diakses: 1 Juli 2020.

${ }^{4}$ Covid-19 telah membuat sebuah kebiasaan baru bagi seluruh dunia, tradisi jabat tangan yang biasa dilakukan, kini harus diminimalisir bahkan diganti dengan pola yang lain untuk menghindari kontak fisik. Pandemi ini akhirnya membuat sebuah pola kenormalan yang baru (new normal) bagi seluruh dunia. 


\section{JURNAL LUXNOS}

Volume 7 Nomor 1, Juni 2021

dengan Allah? Memang sudah ada banyak artikel dan buku yang membahas mengenai persoalan pandemi dari perspektif kedaulatan Allah, seperti bukunya John Lenox dan John Piper, akan tetapi kajian mereka lebih bersifat kajian dogmatis dan filosofis ketimbang kajian secara biblika.

\section{Metode Penelitian}

Metode penelitian yang disajikan dalam artikel ini adalah metode kualitatif dengan pendekatan kepustakaan melalui kajian sumber-sumber data berupa buku dan artikel jurnal yang berkaitan dengan pandemi secara teologis-biblis. Teknik analisis data bersifat deduktif yaitu bertolak dari fakta-fakta umum berkaitan dengan masalah pandemi yang terjadi saat ini, kemudian ditarik kesimpulan yang bersifat khusus mengenai apa yang Alkitab katakan tentang pandemi (penyakit menular). Dengan demikian, teknik analisis data akan menggunakan model Miles dan Huberman yang terdiri dari reduksi data, penyajian data dan penarikan kesimpulan. ${ }^{5}$

\section{Hasil Dan Pembahasan}

\section{Memahami Kedaulatan Allah dan Pandemi Dari Perspektif Alkitab}

Istilah "Pandemi" adalah istilah modern dan tidak pernah digunakan dalam Alkitab. Alkitab menggunakan kata-kata Ibrani dan Yunani kuno yang merujuk kepada pandemi dengan istilah sampar dan tulah. Kata sampar merujuk kepada sebuah penyakit menular dan mematikan yang menyerang dan mempengaruhi manusia secara langsung atau tidak langsung, sedangkan kata tulah merujuk kepada sebuah penyakit yang bersifat biologis dan juga dapat dikaitkan dengan peristiwa yang murni disebabkan oleh alam.

Kata sampar atau tulah di dalam Alkitab digunakan setidaknya 127 kali melalui beberapa kata, yaitu:

(1) Kata Ibrani "dever" (רֶֶֶ? - umumnya diterjemahkan dalam versi bahasa Inggris dari Alkitab sebagai "sampar" atau "wabah")-digunakan 49 kali dalam Kitab Suci Ibrani (Tanakh atau Perjanjian Lama).

(2) Kata Ibrani "nega" (עָגָ - sebagian besar (meskipun tidak selalu) diterjemahkan dalam versi bahasa Inggris dari Alkitab sebagai "wabah")-digunakan 78 kali dalam Kitab Suci Ibrani (Tanakh atau Perjanjian Lama). Kata ini secara khusus

${ }^{5}$ Sugiyono, Metode Penelitian Kombinasi (Bandung: Alfabeta, 2015). 


\section{JURNAL LUXNOS}

Volume 7 Nomor 1, Juni 2021

diterjemahkan ke dalam kata bahasa Inggris "wabah" 65 kali dalam King James Version dari Perjanjian Lama.

(3) Kata Ibrani "makkah" (דָָָּּ - kadang-kadang (meskipun tidak selalu) diterjemahkan dalam versi bahasa Inggris dari Alkitab sebagai "wabah")digunakan 48 kali dalam Kitab Suci Ibrani (Tanakh atau Perjanjian Lama). Khususnya diterjemahkan ke dalam bahasa Inggris kata "wabah" 11 kali dalam King James Version dari Perjanjian Lama.

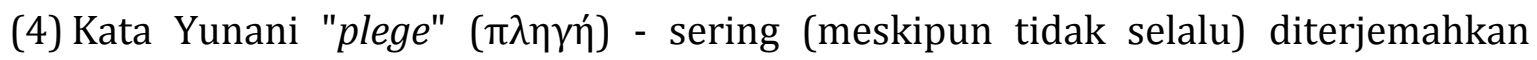
dalam versi bahasa Inggris dari Alkitab sebagai "wabah"- digunakan 21 kali dalam Perjanjian Baru Yunani. Secara khusus diterjemahkan ke dalam bahasa Inggris "wabah" 12 kali dalam King James Version.

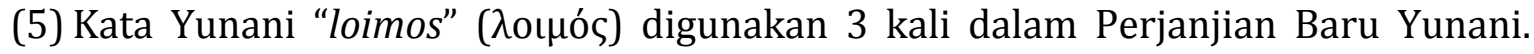
Secara khusus digunakan dua kali sebagai kata bahasa Inggris "sampar" dalam King James Version.

Kata pestilence yang diterjemahkan ke dalam bahasa Indonesia dengan sampar ini pada hakikatnya berkaitan dengan penyakit yang dibawa oleh hewan pengerat tikus. Penyakit sampar atau penyakit pes adalah penyakit yang disebabkan oleh infeksi bakteri Yersinia pestis. Penyakit ini adalah salah satu penyakit mematikan. Ada tiga jenis pes yang digolongkan berdasarkan bagian tubuh yang terlibat, seperti: (1) Pneumonic plague. Jenis pes ini disebabkan oleh infeksi bakteri yang menyebar hingga paru-paru. (2) Septicemic plague. Jenis ini terjadi karena bakteri berkembang biak di dalam darah pengidap pes. (3) Bubonic Plague. Jenis pes ini menimbulkan gejala pembesaran kelenjar getah bening. ${ }^{6}$

Catatan Alkitab pertama kali mengenai penyakit sampar ditemukan dalam kitab Keluaran 5:3, ketika Harun dan Musa meminta ijin kepada Firaun untuk pergi beribadah. Tujuan mereka pergi beribadah adalah agar Tuhan tidak menghukum bangsa Israel

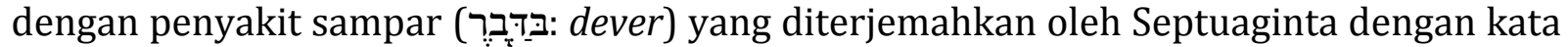

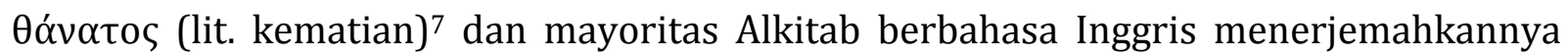

6Emy Rahmawati, "Partisipasi Ibu Dalam Pemasangan Live Trap Terhadap Jumlah Tangkapan Tikus Dan Pinjal Di Desa Sukabumi Kecamatan Cepogo Kabupaten Boyolali," Unnes Journal of Public Health (2013): 1-10.

${ }^{7}$ Para nabi, selalu menghubungkan hukuman dari Tuhan melalui tiga jenis hukuman yaitu pedang, sampar dan kelaparan sebagai tiga kejahatan yang biasanya menyertai satu sama lain (Yer. 29:17). 


\section{JURNAL LUXNOS}

Volume 7 Nomor 1, Juni 2021

dengan 'pestilence'. ${ }^{8}$ Terlihat dari bagian ini bahwa Musa dan Harun menjelaskan kepada Firaun, bahwa jika mereka tidak beribadah maka mereka akan mendapatkan hukuman dari Tuhan dan hukuman itu berupa penyakit menular yang mematikan. Namun, dalam catatan Keluaran, hukuman Tuhan berupa penyakit yang mematikan itu justru pertama kali dicatat pada peristiwa penyakit sampar yang Allah lakukan terhadap ternak-ternak orang Mesir dan mengakibatkan ternak-ternak orang Mesir mengalami kematian.

Selanjutnya kata sampar bukanlah kata yang asing di telinga orang Israel. Ada begitu banyak perjanjian antara Tuhan dan bangsa Israel, di mana Tuhan selalu memberikan peringatan kepada orang Israel agar tidak lalai dalam menjalankan perjanjian antara mereka dengan Tuhan, dari pihak orang Israel Tuhan menuntut ketaatan dan penyembahan mutlak hanya kepada Tuhan. Apabila mereka tidak taat, maka Tuhan akan memberikan penyakit sampar kepada mereka (Im. 26:25; Bil. 8:19; Ul. 28:21). Dalam sejarah bangsa Israel, penyakit sampar yang mematikan ini adalah sesuatu yang sangat menakutkan. Dalam Talmud dan Mishnah dijelaskan mengenai apa yang dimaksud dengan penyakit sampar ini. Beberapa penyakit menular dikutip dalam Talmud, di antaranya adalah bukti utama yang dikaitkan dengan askara. Askara adalah sebuah istilah bagi penyakit ini yang menyerang bagian asfiksia dengan banyak rasa sakit dan dalam waktu singkat, penyakit ini menular dan berbahaya untuk anak-anak. ${ }^{9}$ Sedangkan Mishnah selesai pada abad kedua, memberikan definisi yang sangat menarik berkaitan dengan kata sampar (dèver) yaitu sebuah penyakit yang bisa membunuh dengan cepat, dalam kurun waktu tiga hari saja dapat membunuh 500 warga dalam sebuah kota. ${ }^{10}$

Masalah lain yang sangat menarik muncul dari teks-teks suci yaitu merebaknya penyakit epidemi mematikan di antara babi. Rabi Judah segera memerintahkan puasa di depan umum, kemudian dia ditanya apakah dia berpikir bahwa penyakit itu mungkin menyebar dari hewan ke manusia? Dia menjawab bahwa situasi ini biasanya tidak terjadi, tetapi babi adalah kasus khusus dan bahwa organisme yang terdapat dalam babi memiliki kemiripan dengan tubuh manusia. ${ }^{11}$

${ }^{8}$ Kamus Merriam Webster, mendefenisikan pestilence ini sebagai: penyakit epidemi menular atau infeksi yang mematikan. Sedangkan, secara umum, kata ini dimaknai sebagai penyakit mematikan dan luar biasa yang mempengaruhi seluruh komunitas.

${ }^{9}$ http://it.wikipedia.org/wiki/talmud, diakses: 9 Juli 2020.

10 http://en.wikipedia.org/wiki/judah_haNasi, diakses: 9 Juli 2020.

11 Kottek S.S., Epidemics in ancient Jewish Lore. Isr. J. Med. Sci. (1996): 32, 587-588. 


\section{JURNAL LUXNOS}

Volume 7 Nomor 1, Juni 2021

Kisah penghukuman Tuhan berkaitan dengan penyakit sampar yang mematikan paling jelas terlihat dalam kisah mengenai Raja Daud. Pada waktu itu, Raja Daud menjadi tinggi hati dan melupakan Tuhan. Kemudian Tuhan menghukum Daud dengan meminta Daud untuk memilih hukuman dan hukuman yang dipilih oleh Daud adalah penyakit sampar. Tuhan mendatangkan sampar selama 3 hari (2 Sam. 24:13) dan Alkitab mencatat hampir tujuh puluh ribu rakyat tewas karena penyakit sampar. Catatan Alkitab juga terlihat dengan jelas melalui peristiwa ketika orang-orang Filistin memutuskan untuk mengembalikan Tabut Perjanjian kepada Israel. Mereka memberikan persembahan sebagai penawaran rasa bersalah, "lima borok emas dan lima tikus emas" (I Sam. 6) mengenai interpretasi makna kata Yahudi "ophal" (bengkak atau borok), memang ada sebuah debat sastra yang mempengaruhi etiologi penyakit epidemi ini.

J. P. Griffin, menjawab sebuah laporan sebelumnya, di mana dinyatakan bahwa wabah itu tidak diketahui secara klasik dan melaporkan bahwa pendapatnya membuat dia berpikir penyakit ini sudah dikenal di zaman kuno. Untuk mendukung asumsi ini, dia mengutip beberapa bagian dari Perjanjian Lama (Buku Samuel), keduanya dalam terjemahan yang bernama Septuaginta dan Vulgata, di mana dilaporkan tentang bagaimana orang-orang Filistin dihukum oleh Tuhan. Dia menyatakan bahwa dalam Vulgata, frasa berikut ditulis "... dan tikus muncul di tanah mereka, kematian dan kehancuran ada di seluruh kota". Dalam terjemahan Septuaginta, konsep ini diperluas dengan lebih jelas: "Dia menyerang orang-orang, baik tua maupun muda dengan tumor pecah (borok)", selain itu juga dikutip bahwa lokasi tumor itu berada "di pangkal paha". Karena alasan ini, orang-orang Filistin yang menangkap Tabut Perjanjian dengan mengirimkannya kembali, mengakui kesalahan mereka dan memberikan persembahan "lima tumor emas dan lima tikus emas menurut jumlah penguasa Filistin kota mereka".12 Sesuai dengan referensi alkitabiah ini penulis menyimpulkan bahwa masalah wabah dengan bubo yang terkait sudah terbentuk pada zaman kuno dan disebabkan oleh tikus.

Hal menarik dari ayat-ayat yang berkaitan dengan penyakit sampar dalam Perjanjian Lama adalah keseluruhan ayat tersebut menjelaskan bahwa penyakit sampar didatangkan oleh Tuhan sebagai penghukuman terhadap keberdosaan dan kebersalahan manusia kepada Tuhan. Tuhan adalah subjek dari kata kerja tersebut, frasa yang selalu sama ditemukan dalam semua ayat adalah selalu dimulai dengan kalimat "Aku (Allah) akan mendatangkan penyakit sampar...”.

12J. P. Griffin, Bubonic plague in biblical times. J. R. Soc.Med (2000): 93, 449. 


\section{JURNAL LUXNOS}

Volume 7 Nomor 1, Juni 2021

Namun yang perlu dicatat adalah tidak semua penghukuman dari Tuhan adalah akibat dari keberdosaan manusia. John C. Lenox menjelaskannya dalam sebuah kalimat sederhana "menurut Alkitab, tidaklah benar untuk menyimpulkan bahwa jika seseorang menderita penyakit akut atau mengalami kecelakaan, maka ia pasti memiliki dosa serius yang tersembunyi". ${ }^{13}$ Lennox dengan tegas menolak pendapat mengenai Allah sebagai penyebab dari kejahatan (penderitaan) yang manusia alami. Bagi Lennox ada dua penyebab utama penderitaan yaitu kejahatan moral dan kejahatan alamiah. Ia menulis "pengajaran Kristen sangatlah jelas bahwa tidak semua bencana dan penyakit adalah penghukuman Allah (seperti dalam kasus Ayub), namun ada perkara-perkara yang memang merupakan penghakiman Allah."14

Saya menyetujui pendapat Lennox ini namun hanya pada sebagian saja, karena jika melihat dalam doanya di pentahbisan bait suci, Salomo meninggalkan ruang yang menarik dengan ambiguitas antara epidemi dan hukuman ilahi. Dia memohon kepada Yahweh untuk mendengarkan ketika orang-orang berdoa kepada-Nya dalam konteks epidemi atau bencana lain. Salomo memohon agar Yahweh mengampuni dan berurusan dengan setiap orang sesuai dengan keadaan hati mereka (2Taw. 6:28-30). Dalam Mazmur 91 juga dijelaskan bahwa hanya dengan bernaung di depan Allah yang maha tinggi sajalah seseorang dapat terlepas dari bahaya epidemi, pandemi dan dari penyakit sampar. Dari dua bagian Firman ini, setidaknya memberikan sedikit gambaran bahwa jika perlindungan itu hanya datang dari Tuhan dan jika Salomo memohon agar Allah mengampuni dan berurusan dengan setiap orang sesuai dengan keadaan hati orang tersebut, maka penderitaan (secara khusus pandemi) adalah bagian dari ketetapan Tuhan.

Dalam Perjanjian Baru, penyakit sampar disebutkan dalam kaitan dengan kedatangan Yesus untuk kedua kalinya. Bahwa sebelum kedatangan Yesus yang kedua kalinya, akan ditandai terlebih dahulu dengan adanya penyakit sampar yang mematikan (Luk. 21:11; Why. 6:8; 18:8). Alkitab dengan jelas menunjukkan bahwa Allah menggunakan penyakit sampar baik itu sebagai penghukuman atau peringatan adalah untuk mencapai tujuan ilahi dari kehendak-Nya. Penyakit sampar adalah alat di tangan Tuhan untuk menghukum orang berdosa, memperingatkan orang akan kesalahan dan juga menjadi manifestasi kemahakuasaan dan kekudusan Allah. Dengan kata lain, kisahkisah Perjanjian Lama (dan juga Perjanjian baru) tentang penyakit menular (penyakit

13John C. Lennox, Where Is GOD in a Coronavirus World? (Di Mana Allah Dalam Dunia Dengan Virus Corona ?) (Surabaya: Literatur Perkantas, 2020), 30.

${ }^{14}$ Ibid, 32. 


\section{JURNAL LUXNOS}

Volume 7 Nomor 1, Juni 2021

sampar) aktual sangat menakutkan, meskipun mereka juga memiliki implikasi instruktif dan konstruktif. Ketika bencana mengambil musuh-musuh Israel, signifikansi mereka secara khas melampaui kisah yang jahat. Bahkan ketika itu terjadi pada penekan Israel dan berkontribusi pada pembebasannya, kisah-kisah itu dapat memiliki keunggulan karena mereka membahas Israel sendiri.

Apakah dengan menurunkan penyakit sampar yang membunuh begitu banyak orang dan apakah dengan menubuatkan Kristus yang akan datang kedua kalinya dengan didahului oleh penyakit sampar (pandemic) menjadikan Allah menjadi Allah yang jahat? Paul Copan dalam bukunya God Is a Moral Monster, menjelaskan bahwa Allah justru Allah yang sangat baik dan penuh dengan kerendahan hati, Allah tidak pernah sekalipun menjadi Allah yang jahat bahkan dalam sepersekian detik pun, sejak dari penciptaan manusia sampai pada akhir nanti kehidupan manusia, Allah tetaplah Allah yang baik.

Menurut Paul Copan, penciptaan manusia menurut gambar dan rupa Allah dapat disebut sebagai "menyebarkan kekayaan" oleh Tuhan. Tuhan melimpahkan kebaikanNya kepada ciptaan-Nya yang hidup, bergerak dan ada di dalam diri-Nya. Meskipun Tuhan menciptakan dengan bebas dan tanpa batasan, Tuhan penuh dengan sukacita dan cinta untuk berbagi kebaikan dengan makhluk-Nya. Dia mengizinkan kita para pembawa citra-Nya, untuk berbagi (dengan cara yang sangat terbatas) dalam karakteristiknya dan memampukan kita untuk berpartisipasi dalam kehidupan komunitas Ilahi yakni kehidupan yang memenuhinya dengan sukacita yang besar (lihat 2 Pet. 1: 4). Tuhan menganugerahi kita pujian besar dengan posisi istimewa dan kemampuan. Semua ini mencerminkan keindahan sifat Tuhan sendiri."15 Copan juga menjelaskan bahwa penghukuman bahkan pandemi melalui penyakit menular yang Allah berikan kepada manusia, malah menunjukkan kebaikan Allah bahwa Allah peduli dengan manusia. Ia menjelaskan bahwa "kecemburuan dan kemarahan Tuhan muncul dari cinta dan perhatian, bukan dari kesombongan atau ketidakdewasaan yang terluka. Ateis Baru menolak gagasan hak prerogatif Tuhan yang sah atas manusia karena gagasan tentang penghakiman ilahi atau kemarahan atau kecemburuan membuat mereka tidak nyaman. Tetapi seperti Aslan dari Narnia, Yahweh meskipun murah hati dan penyayang, tidak bisa dianggap enteng. Tuhan menjadi cemburu atau marah justru karena Dia peduli."16 Kecemburuan Tuhan bahkan melalui penghukuman dengan penyakit menular (pandemi) sekalipun adalah upaya Tuhan untuk melindungi makhluk-makhluknya dari bahaya

15Paul Copan, Is God a Moral Monster? Making Sense of the Old Testament God (Grand Rapids Michigan: Baker Books, 2011), 43-44.

16 Ibid, 61-62. 


\section{JURNAL LUXNOS}

Volume 7 Nomor 1, Juni 2021

mencelakakan diri sendiri yang lebih besar. Kita dapat merusak diri kita sendiri dengan mengejar ilah-ilah lain yang diciptakan menurut gambar kita sendiri. Kecemburuan Tuhan berpusat pada orang lain.

Tuhan adalah pencipta dan pemberi kehidupan semua yang baik. Ia menginginkan agar makhluk-makhluknya menjalani kehidupan sebagaimana mestinya. Ketika seseorang bertindak dengan cara yang menyangkal kehidupan (misalnya, terlibat dalam perzinahan, pornografi, melanggar janji atau hanya menekan kebenaran tentang Tuhan), kecemburuan Tuhan muncul sehingga orang tersebut dapat meninggalkan tujuan pencarian kematiannya dan kembali ke hidup berkelimpahan yang ditemukan dalam kehidupan yang ditelantarkan kepada Tuhan. ${ }^{17}$ Jadi, pandemi adalah jalan yang digunakan Allah untuk melindungi ciptaan-Nya dari kecelakaan yang lebih besar. Allah tetaplah Allah yang baik dan berdaulat bahkan ketika penyakit menular seperti Sampar, Covid-19 dan lainnya telah menjadi pandemi dan membuat banyak manusia mengalami kematian.

\section{Pandemi dan Kedaulatan Allah}

Alkitab, secara khusus Perjanjian Lama memperlihatkan bahwa pandemi (penyakit menular) adalah bagian dari rencana Allah untuk menghukum keberdosaan manusia (baik itu musuh orang Israel maupun orang Israel itu sendiri atau sebagai peringatan kepada umat-Nya untuk tidak melakukan dosa). Hal ini berarti bahwa penderitaan dan penyakit menular yang membunuh begitu banyak orang adalah bagian dari ketetapan Tuhan. Jika demikian, apakah berarti bahwa Allah adalah Allah yang jahat? John Piper dalam bukunya Kristus dan virus Corona menjelaskan bahwa keberadaan virus Corona tidak menunjuk kepada kecemaran, kesalahan atau kejahatan Allah karena Allah tetaplah Allah yang baik. ${ }^{18}$ Segala sesuatu ada dalam kehendak dan rencana Allah bahkan Allah berdaulat atas virus Corona (pandemi; penekanan penulis).

Salah satu pengakuan mendasar dalam iman Kristen adalah bahwa Allah adalah pencipta dunia beserta dengan segala isinya. Melalui pengakuan ini, secara tidak langsung telah menjadi dasar dari kehidupan etis dan religius umat Kristen bahkan melalui pengakuan bahwa Allah adalah pencipta dari segala sesuatu telah membawa Iman Kristen kepada pengakuan yang lebih luas bahwa tidak ada apapun di dalam dunia ini yang terjadi di luar dari kendali dan ketetapan Allah.

\footnotetext{
17 Ibid, 65-66.

18John Piper, Kristus Dan Virus Corona (Surabaya: Literatur Perkantas, 2020), 33.
} 


\section{JURNAL LUXNOS}

Volume 7 Nomor 1, Juni 2021

Louis Berkhof dengan jelas menyatakan bahwa Allah dengan penuh kedaulatan sejak dari kekekalan menetapkan apa saja yang akan terjadi dan melakukan karya kedaulatan-Nya dalam kehendak-Nya atas semua ciptaan, baik yang alamiah maupun yang rohani, sesuai dengan rencana yang telah Ia tetapkan sejak semula. Hal ini sangat sesuai dengan apa yang diungkapkan oleh Paulus ketika Ia berkata bahwa Allah "di dalam segala sesuatu bekerja menurut keputusan kehendak-Nya" (Ef. 1:11) ${ }^{19}$. Allah berkuasa secara penuh kepada segala sesuatu yang ada di dalam dunia, mulai dari partikel terkecil dari alam semesta sampai pada hal-hal terbesar dalam dunia, segala sesuatu ada dalam kendali dan kedaulatan Allah yang kudus ${ }^{20}$. Hal ini senada dengan apa yang disampaikan oleh Calvin "Tetapi setiap orang yang telah diajar oleh bibir Kristus bahwa semua rambut kepalanya terhitung (Mat 10:30) akan melihat lebih jauh untuk suatu penyebab dan akan menganggap bahwa semua kejadian diatur oleh rencana rahasia Allah ${ }^{21}$. Allah berdaulat mutlak atas segala sesuatu termasuk Kedaulatan Allah yang mutlak tersebut tidak dipengaruhi oleh sesuatu apapun di luar diri-Nya

B. Warfield mengomentari hal ini dengan sangat jelas bahwa di seluruh Perjanjian Lama, di balik proses alam, perjalanan sejarah, dan keberuntungan dari setiap kehidupan individu, selalu ada dalam pandangan tangan yang mengatur. Tuhan mengerjakan rencana-Nya yang telah terbentuk sebelumnya sebuah rencana yang cukup luas untuk mencakup keseluruhan alam semesta, cukup menit untuk memusatkan perhatian pada detail terkecil, dan mengaktualisasikan dirinya dengan kepastian yang tak terhindarkan dalam setiap peristiwa yang terjadi."22

Allah berdaulat mutlak atas seluruh dunia, termasuk di dalam pandemi yang terjadi di seluruh dunia baik dari masa lampau, yang sekarang kita hadapi (Covid-19) dan yang mungkin nanti akan kita hadapi di masa depan. Piper menulis bahwa karena itu, virus corona dikirim oleh Allah. Ini bukan saatnya mengadopsi pandangan yang sentimental terhadap Allah. Ini adalah musim yang pahit dan Allah menetapkannya. Allah mengaturnya demikian dan Ia akan mengakhirinya. Tidak ada sebagian pun darinya berada di luar kendali-Nya. Hidup dan mati ada di tangan-Nya. ${ }^{23}$ Pandemi adalah bagian dari ketetapan Allah yang maha agung dan besar. Kita berhutang cukup banyak

\footnotetext{
${ }^{19}$ Louis Berkhof, Teologi Sistematika, Doktrin Allah (Surabaya: Momentum, 1993), 179.

20R. C. Sproul, Kaum Pilihan Allah (Malang: SAAT, 1995), 15.

21Yohanes Calvin, Institutio (Jakarta: BPK Gunung Mulia, 2009), 150.

22B. B. Warfield, Biblical and Theological Studies (New York: Oxford University Press, 1929), 276.

23Piper, Kristus Dan Virus Corona, 39.
} 


\section{JURNAL LUXNOS}

Volume 7 Nomor 1, Juni 2021

pada buku John Piper "Kristus dan virus corona", untuk menilai apa yang Allah sedang kerjakan melalui virus Corona.

Piper menjelaskan ada enam argumentasi mengenai hal tersebut (namun saya hanya membahas alasan pertama saja) yaitu virus Corona sedang mengajarkan tentang kengerian moral manusia, mengenai betapa bejat dan jahatnya hati manusia sejak kejatuhan manusia ke dalam dosa. Virus Corona memiliki dua sisi, sebagai penghukuman kepada mereka yang tidak percaya dan sekaligus sebagai pemurnian bagi mereka yang percaya kepada Yesus. ${ }^{24}$ Pandangan Piper ini sejalan dengan pandangan Calvin. Calvin percaya bahwa gempa bumi, tsunami dan kekejaman lainnya harus dipandang sebagai penghukuman Allah sebagai tanggapan atas dosa manusia. Bahkan penebusan tidak mampu melepaskan diri dari dilema ini selama masa hidup orang percaya. Oleh karena itu, dalam pemikiran Calvin, kejahatan memiliki realitas yang berbeda dalam bentuk pertentangan terhadap Allah. ${ }^{25}$

Kejatuhan manusia ke dalam dosalah yang menyebabkan kejahatan itu masuk ke dalam dunia. Meskipun demikian, Calvin mengakui bahwa kejahatan atau penderitaan masih merupakan sesuatu yang berada dalam providensinya Allah dan tetap merupakan misteri di hadapan manusia. Kejahatan atau penderitaan adalah cara Allah untuk menghukum manusia atas segala dosa dan kesalahannya, dan juga cara Allah untuk melindungi umat pilihan-Nya.

\section{Kesimpulan}

Berdasarkan penelusuruan biblical dan teologis tentang kedaulatan Allah dan virus Corona, kita dapati bahwa virus Corona adalah alat di tangan Tuhan untuk menghukum orang berdosa dan juga pemurniaan bagi orang percaya. Hanya dengan datang dan hidup sesuai dengan Firman Tuhan saja, manusia dapat menghadapi virus corona ini (seperti dalam doa Salomo dalam penahbisan Bait Suci dan juga Mazmur 91). Allah berdaulat mutlak dalam memelihara dunia, dan Virus Corona adalah salah satu cara Allah untuk memulihkan kembali dunia yang sudah rusak dan penuh dengan dosa, dan mungkin virus ini juga dipakai oleh Allah untuk mencegah sesuatu yang lebih buruk yang mungkin akan terjadi di masa depan, mengingat bahwa Allah berdaulat atas segala sesuatu.

24 Ibid, 57-62.

25Theodore Plantinga, Learning to Live with Evil (Grand Rapids Michigan: Eerdmans, 1982), 62. 


\section{JURNAL LUXNOS}

Volume 7 Nomor 1, Juni 2021

Dunia saat ini, sedang menuju sebuah perang dunia yang ketiga, dan perang dunia yang ketiga ini berdampak lebih hebat dari dua perang dunia sebelumnya, karena perang dunia ketiga ini lebih bersifat perang ekonomi ketimbang perang fisik. China dan Amerika menjadi pelopor dari perang ekonomi ini, sehingga tidak heran bahwa di Amerika, jumlah kematian akibat Corona ini sangat tinggi dan dengan sendirinya telah meruntuhkan kekuatan ekonomi Amerika, begitu juga dengan China, negara pertama yang terinfeksi virus ini. ${ }^{26}$ Melalui Corona, Allah sedang memelihara dunia untuk tetap terjaga, Allah sedang membaharui bumi dari segala macam upaya pengrusakan dan eksploitasi berlebihan dari umat manusia untuk menguasai ekonomi dunia, karena seperti yang terlihat bahwa kekayaan alam di dunia, telah dieksploitasi besar-besaran untuk memuaskan hawa nafsu manusia, bahkan hampir seluruh hutan (terutama di Indonesia) telah berubah fungsinya. Allah berdaulat atas segala sesuatu termasuk untuk mendatangkan virus Corona, dan Allah berdaulat untuk memelihara umat-Nya dari virus ini, dan terlebih lagi untuk melenyapkan virus ini dari seluruh dunia.

\section{Referensi}

Berkhof, Louis. Teologi Sistematika, Doktrin Allah. Surabaya: Momentum, 1993.

Calvin, Yohanes. Institutio. Jakarta: BPK Gunung Mulia, 2009.

Copan, Paul. Is God a Moral Monster? Making Sense of the Old Testament God. Grand Rapids Michigan: Baker Books, 2011.

Lennox, John C. Where Is God in a Coronavirus World? (Di Mana Allah Dalam Dunia Dengan Virus Corona?). Surabay: Literatur Perkantas, 2020.

Piper, John. Kristus Dan Virus Corona. Surabaya: Literatur Perkantas, 2020

Plantinga, Theodore. Learning to Live With Evil. Grand Rapids Michigan: Eerdmans, 1982.

Rahmawati, Emy. "Partisipasi Ibu Dalam Pemasangan Live Trap Terhadap Jumlah Tangkapan Tikus dan Pinjal di Desa Sukabumi, Kecamatan Cepogo, Kabupaten Boyolali". Unnes Journal of Public Health, 2013.

Sproul, R.C. Kaum Pilihan Allah. Malang: SAAT, 1995.

Sugoyono. Metode Penelitian Kombinasi. Bandung: Alfabeta, 2015.

26Piper, Kristus Dan Virus Corona. 


\section{JURNAL LUXNOS}

Volume 7 Nomor 1, Juni 2021

Warfield, B.B. Biblical and Theological Studies. New York: Oxford University Press, 1929.

\section{Daftar Laman}

Judah ha-Nasi, diakses dari https://en.wikipedia.org/wiki/Judah_ha-Nasi.

J. P. Griffin, Bubonic plague in biblical times. J. R. Soc.Med, 2000

Kottek S.S. Epidemics in ancient Jewish Lore. Isr. J. Med. Sci, 1996

Ketahui Beda Wabah, Pandemik, Endemik, dan Epidemik, diakses dari https://www.medcom.id/rona/kesehatan/dN60dMqk-ketahui-beda-wabahpandemik-endemik-dan-epidemik.

Talmud, diakses dari https://it.wikipedia.org/wiki/Talmud.

WHO Coronairus (Covid-19) Dashboard, diakses dari https://covid19.who.int/table. 